\title{
PARENTERAL NUTRITION IN NEONATUS AND COMPATIBILITY ISSUES: A REVIEW ARTICLE
}

\author{
YELLY OKTAVIA S*, HELMI ARIFIN, RAHMI YOSMAR
}

Faculty of Pharmacy, University of Andalas, Padang, 25163, West Sumatera, Indonesia. Email: yelly.sari@gmail.com

Received: 15 October 2016, Revised and Accepted: 10 November 2016

\begin{abstract}
Intravenous drug administration in Neonatal Intensive Care Unit is critical because of poor venous access, polymedication, fluid restriction, and low infusion rate. Since parenteral nutrition (PN) is infused intravenously, it is often considered as a vehicle for medication administration. Medications may be added to PN formulations in an effort to decrease fluid requirements, reduce the need for Y-site injections, reduce the possibility of line contamination due to manipulation, and decrease labor time required for drug administration. Risk is further increased by inadequate information on the physicochemical compatibility of drugs
\end{abstract}

Keywords: Parenteral nutrition, Neonatus, Compatibility

(C) 2017 The Authors. Published by Innovare Academic Sciences Pvt Ltd. This is an open access article under the CC BY license (http://creativecommons. org/licenses/by/4. 0/) DOI: http://dx.doi.org/10.22159/ajpcr.2017.v10i2.15697

\section{INTRODUCTION}

Malnutrition is a state in which a deficiency of nutrients such as energy, protein, vitamins and minerals causes measurable adverse effects on body composition, function or clinical outcome. Malnutrition is both a cause and a consequence of ill health. It is common and increases a patient's vulnerability to disease. Methods to improve or maintain nutritional intake are known as nutrition support. These include oral nutrition support - for example, fortified food, additional snacks and/or sip feeds, enteral tube feeding - the delivery of a nutritionally complete feed directly into the gut via a tube and parenteral nutrition (PN) the delivery of nutrition intravenously. These methods can improve outcomes, but decisions on the most effective and safe methods are complex [1].

Ever since the late 1960s, when Wilmore and Dudrick first published their research on central venous alimentation, which promoted growth in an infant [2], PN has been an important adjunctive therapy for many patients with catabolic medical conditions including the elderly. Whether these patients are receiving this therapy in an acute-care setting, a long-term care setting, or at home, pharmacist should be knowledgeable about the therapy and be able to assess its effectiveness as well as prevent complications associated with total PN [3].

Over the last four decades, PN has become an important primary (e.g., intestinal failure) and adjunctive therapy of disease states. PN is commonly used in such condition as severe pancreatitis, shortbowel syndrome, inflammatory bowel disease exacerbations, and gastrointestinal (GI) fistulae, as well as in critically ill patients, infants with very low birth weight, and patients with cancer receiving hematopoietic cell transplantation [4].

\section{PN INPEDIATRIC}

PN is used to treat children that cannot be fully fed by oral or enteral route, for example, due to severe intestinal failure [7]. Intestinal failure occurs when the GI tract is unable to ingest, digest and absorb sufficient macronutrients and/or water and electrolytes to maintain health and growth. Children differ from adults in that their food intake must provide sufficient nutrients not only for the maintenance of body tissues but also for growth. This is particularly true in infancy and during adolescence when children grow extremely rapidly. At these times, children are particularly sensitive to energy restriction because of high basal and anabolic requirements [8,9].
The ability to provide sufficient nutrients parenterally to sustain growth in infants and children suffering from intestinal failure or severe functional intestinal immaturity represents one of the most important therapeutic advances in pediatrics over the last three decades. Improvements in techniques for artificial nutritional support now ensure that children in whom digestion and absorption are inadequate or who are unable to eat normally no longer need to suffer from the serious consequences of malnutrition including death $[10,11]$.

\section{PN for newborn premature infants}

PN is the intravenous (IV) infusion of all nutrients necessary for metabolic requirements and growth. PN refers to the IV infusion of nutrients by peripheral or central vein. Enteral nutrition (EN) is provided by oral or gavage feedings. PN is commonly indicated in neonates experiencing congenital malformation of the GI tract, gastroschisis, meconium and paralytic ileus, short-bowel syndrome, necrotizing enterocolitis, respiratory distress syndrome, extreme prematurity, sepsis, and malabsorption. The ability to provide EN and PN over the last four decades has significantly improved the overall survival of newborns when other options of adequate nutritional support were not possible [12].

The goal of PN is to initially provide sufficient nutrients to prevent negative energy and nitrogen balance and essential fatty acid deficiency and support normal rates of intrauterine growth of appropriate composition without increased significant morbidity. Fear of toxicity and metabolic imbalance has alerted clinicians to use PN with caution, especially in the sickest and most premature infants. An increasing number of practitioners appreciate that this cautionary management has resulted in suboptimal nutrition intake of these infants. Practitioners have speculated that this cautionary practice contributed in part to national growth failure outcome statistics published of infants extremely low in birth weight (ELBW; $<1000 \mathrm{~g}$ ) and appropriate for gestational age (AGA; weight $\geq 10^{\text {th }}$ percentile norm) born from 1995 to 1996 . When assessed at discharge ( $\approx 36$ weeks' corrected age) $99 \%$ of these infants had significant growth failure with weights less than the $10^{\text {th }}$ percentile compared with intrauterine growth standards $[12,13]$. Longer-term statistics indicate that a significant percentage of infants born very low in birth weight (VLBW; <1500 g) may suffer substantial neurodevelopmental deficits in part attributable to inadequate nutritional support in the neonatal period [14]. In more recent years, the earlier introduction and more aggressive advancement of PN were shown to be safe and effective, even in the smallest and most immature infants [15-19]. 
Timely intervention with PN begins with the provision of glucose as soon as possible after birth with amino acids within the first 12 hrs, IV fat within the first 24-48 hrs, and trophic feeding within the first 24 hrs [20]. The optimal use of routine PN for nutritional support of LBW and VLBW infants may influence short-term outcomes such as lower propensity to infection and shortened hospital stay, as well as longer-term outcomes such as decreased growth deficits, [56] improved neurodevelopment, and overall morbidity [21-23]. Indications that are generally recognized as those that necessitate PN for newborns are listed in Table 1.

\section{Components of PN solutions}

PN provides some or all nutrients of basal metabolism and growth for fluid, energy, macronutrients (protein, carbohydrate, and fat), and micronutrients (electrolytes, major minerals, trace minerals, and vitamins) [24-31]. Recommended intakes for premature and term neonatesare summarized in Table 2.

An overview of fluid, macronutrient, and micronutrient recommendations follows.

\section{Fluid}

On day one of life, maintenance fluids are met with a range between 80 and $140 \mathrm{~mL} / \mathrm{kg} / \mathrm{d}$ if the environment of the baby increases insensible water losses and $60-100 \mathrm{~mL} / \mathrm{kg} / \mathrm{d}$ in environments with increased humidity. Thereafter, fluid volume is advanced as tolerated to $120-180 \mathrm{~mL} / \mathrm{kg} / \mathrm{d}$. Maximal fluid volume varies with individual management [25].

\section{Macronutrients}

Carbohydrate (dextrose) and fat (lipid emulsions) provide the energy needed to meet the demands of the circulatory, respiratory, neurological, and muscular systems, and when provided in adequate amounts, spare protein (amino acids) to support cell maturation, remodeling, growth, activity of enzymes, and transport proteins for all body organs. Energy needs may be increased with infection, chronic lung disease, healing, growth, and in babies who have experienced intrauterine growth restriction. Energy needs may be decreased with sedation, mechanical ventilation, and after tracheostomy placement.

\section{Initiation and advancements of macronutrients in PN solutions} The use of PN is suggested to support all ill and premature babies $<1500 \mathrm{~g}$ that cannot sustain at least $\sim 60 \mathrm{kcal} / \mathrm{kg} / \mathrm{denterally}$ and initiation is recommended during the first $24 \mathrm{hrs}$ of life to avoid excessive protein losses. The premature infant who is not growing, not septic, and not unduly stressed requires an energy intake of about $50 \mathrm{kcal} / \mathrm{kg} / \mathrm{d}$ for

Table 1: Indications for PN support and route of administration for newborn infants who require intensive care

\begin{tabular}{|c|c|}
\hline $\begin{array}{l}\text { Route of PN } \\
\text { administration }\end{array}$ & Indication for PN \\
\hline Peripheral & $\begin{array}{l}\text { Temporary supply of nutrients }<2 \text { weeks: } \\
\downarrow 2 \text { Enteral intake } \\
\text { Functional gut immaturity } \\
\text { Temporary feeding intolerance } \\
\text { Medical instability }\end{array}$ \\
\hline Central & $\begin{array}{l}\text { Prolonged nonuse of the (GI) tract }>2 \text { weeks } \\
\text { Short-bowel syndrome } \\
\text { Surgical GI disorders } \\
\text { Necrotizing enterocolitis } \\
\text { Intractable diarrhea } \\
\text { Meconium ileus } \\
\text { Line access in infants extremely low } \\
\text { In birth weight }<1000 \mathrm{~g}\end{array}$ \\
\hline
\end{tabular}

PN: Parenteral nutrition, GI: Gastrointestinal resting energy expenditure, activity, and occasional cold stress [33-37], with as little as $\sim 1-1.5 \mathrm{~g}$ protein $/ \mathrm{kg} / \mathrm{d}$ to preserve endogenous protein stores $[17,38,39]$. At least $60 \mathrm{kcal} / \mathrm{kg} / \mathrm{d}$ is thought to meet energy requirements during acute sepsis [40]. Provision of $>70 \mathrm{kcal} / \mathrm{kg} / \mathrm{d}$ and 2.7-3.5 g protein $/ \mathrm{kg} / \mathrm{d}$ has been demonstrated to support growth and positive nitrogen balance in preterm infants [36]

\section{Carbohydrate}

Carbohydrate is delivered in $2.5-70 \%$ dextrose solutions that provide $3.4 \mathrm{kcal} / \mathrm{g}$. Glucose is the energy source for all cells and is essential for the central nervous system, erythrocytes, and other tissues. To ensure a stressed premature infant receives an adequate but not excessive amount of glucose, the amount of carbohydrate delivered in the form of dextrose is commonly initiated at the endogenous hepatic glucose production and utilization rate of $4-6 \mathrm{mg} / \mathrm{kg} /$ minutes [41]; 8-10 mg/kg/minutes in ELBW infants provides $40-50 \mathrm{kcal} / \mathrm{kg} / \mathrm{d}$ and preserves carbohydrate stores [32].

Frequently smaller, more unstable premature infants develop hyperglycemia due to decreased insulin production and insulin resistance. Glucose infusion rates (GIRs) for these babies may need to be limited to $4 \mathrm{mg} / \mathrm{kg} /$ minutes or less, while larger preterm infants or term infants can often tolerate up to $8 \mathrm{mg} / \mathrm{kg} /$ minutes initially $[34,42]$. Once the GIR supports acceptable serum glucose values, it is advanced in a gradual, stepwise fashion $(0.5-1 \mathrm{mg} / \mathrm{kg} /$ minute) to a suggested maximum glucose oxidative rate for neonates of $12-13 \mathrm{mg} / \mathrm{kg} /$ minutes to support growth and maintained there unless serum glucose values change significantly $[43,44]$.

In most situations, a glucose concentration $>12.5 \%$ is not necessary [34]. However, a higher glucose concentration may be needed when fluid intake is severely restricted or when the amounts of protein and/or fat are limited [34]. Excessive carbohydrate delivery above the amount that can be oxidized for energy and glycogen storage will lead to an increase in basal metabolic rate [45], fat deposition, cholestasis [46], hepatic steatosis [47], or overfeeding as described by the provision of energy in excess of needs for normal growth [47]. GIR $>26 \mathrm{mg}$ glucose $/ \mathrm{kg} /$ minutes may contribute to infiltrates of fat in the liver [48].

Practically, a premature infant who is able to tolerate a fluid volume of $140-150 \mathrm{~mL} / \mathrm{kg} / \mathrm{d}$ will meet macronutrient needs for growth if provided a dextrose concentration of $10 \%$ ( $10-10.5 \mathrm{mg}$ glucose $/ \mathrm{kg} / \mathrm{minutes})$ or $12.5 \%$ ( $12-13 \mathrm{mg}$ glucose $/ \mathrm{kg} /$ minutes); if the protein and fat intakes are both at least $3 \mathrm{~g} / \mathrm{kg} / \mathrm{d}$, the solutions will approximate 80-95 and $100-105 \mathrm{kcal} / \mathrm{kg} / \mathrm{d}$, respectively. Additional dextrose delivery from IV medication needs to be taken into account when calculating the GIR for individual babies $[49,66]$.

To optimize the amount of fluid available to provide nutrition to the small premature baby while trying to maintain a euglycemic state, it may be necessary to double-concentrate the continuous infusions that deliver medications and run them at lower rates. Consultation with the pharmacist can ensure that these lower medication infusion rates are the adequate for optimum clinical effectiveness of the IV drug. If further fluid restriction or dextrose limitation is necessary, other options to optimize the delivery of glucose are to minimize the amount of fluids delivered with IV medications or needed to keep a line patent and decrease the dextrose concentration of the IV medication solution so that slightly more dextrose can be delivered from the PN solution and/or increase the dextrose concentration of the IV medication solution to equal that of the PN solution while ensuring glucose tolerance [12].

Protein

Protein is delivered as free amino acids in solutions developed specifically for pediatric patients with an amino acid profile that is higher in amounts of amino acids believed to be conditionally essential for premature infants (aspartate, glutamate, taurine, and tyrosine) and with lesser amounts of glycine compared with adult solutions. Cysteine 
Table 2: Usual daily requirements of nutrients in PN solutions for preterm and term infants

\begin{tabular}{|c|c|}
\hline Nutrient additive & Usual daily requirements in PN \\
\hline Neonatal amino acid & $\begin{array}{l}\text { For maintenance: } \\
1.5-2.5 \mathrm{~g} / \mathrm{kg} / \mathrm{d} \\
\text { For ELBW infants, begin at a minimum of } 1.5 \mathrm{~g} / \mathrm{kg} / \mathrm{d} \text { as Soon as possible. } \\
\text { Goals for growth: } \\
3.5 \mathrm{~g} / \mathrm{kg} / \mathrm{d} \text { for }<1000 \mathrm{~g} \\
3.0 \mathrm{~g} / \mathrm{kg} / \mathrm{d} \text { for } 1000-2500 \mathrm{~g} \\
2.5 \mathrm{~g} / \mathrm{kg} / \mathrm{d} \text { for }>2500 \mathrm{~g} \\
4.0 \mathrm{~g} / \mathrm{kg} / \mathrm{d} \text { for some infants with } \\
\text { greater needs }\end{array}$ \\
\hline Cysteine hydrochloride & $\begin{array}{l}40 \mathrm{mg} / \mathrm{g} \text { of amino acids ( } 120 \mathrm{mg} / \mathrm{kg} \text { maximum) } \\
\text { Refer to acetate guidelines for ELBW infants (see below under excess anions) }\end{array}$ \\
\hline Dextrose & $\begin{array}{l}\text { For maintenance: } \\
4-6 \mathrm{mg} / \mathrm{kg} / \mathrm{min} \text { (endogenous hepatic glucose } \\
\text { production) } \\
8-10 \mathrm{mg} / \mathrm{kg} / \mathrm{min} \text { (preserves carbohydrate stores) } \\
\text { Goals for growth: } 12-13 \mathrm{mg} / \mathrm{kg} / \text { minutes } \\
\text { Usual maximum concentration: } \\
12.5 \% \text { peripheral route } \\
20-25 \% \text { central route }\end{array}$ \\
\hline Lipid ( $20 \%$ emulsion from $100 \%$ soy oil) & $\begin{array}{l}0.5-4.0 \mathrm{~g} / \mathrm{kg} / \mathrm{d} \text {; begin } 0.5-1.0 \mathrm{~g} / \mathrm{kg} / \mathrm{d} \text { and advance by } 0.5-1.0 \mathrm{~g} / \mathrm{kg} / \mathrm{d} \\
\text { Essential fatty acids met with } 1.0 \mathrm{~g} / \mathrm{kg} / \mathrm{d} \text { and at least } 80 \mathrm{kcal} / \mathrm{kg} / \mathrm{d} \\
\text { Delivered as a component to the amino acid-glucose solution (admixture) or as a separate } \\
\text { solution }\end{array}$ \\
\hline Energy & $\begin{array}{l}\text { Goals for maintenance } \\
\text { Preterm/term: } 60 \mathrm{kcal} / \mathrm{kg} / \mathrm{d} \\
\text { Goals for growth } \\
\text { Preterm: } 90-110 \mathrm{kcal} / \mathrm{kg} / \mathrm{d} \\
\text { Term: } 80-90 \mathrm{kcal} / \mathrm{kg} / \mathrm{d} \\
\text { Dextrose }(40-60 \%), \text { lipid }(40-50 \%) \text {, protein }(10-15 \%)\end{array}$ \\
\hline Carnitine & $2-10 \mathrm{mg} / \mathrm{kg} / \mathrm{d}$ not to exceed $50 \mathrm{mg} / \mathrm{kg} / \mathrm{d}^{69}$ \\
\hline Heparin & $\begin{array}{l}1 \mathrm{unit} / \mathrm{mL} \text { not to exceed } 137 \text { units/d } \\
0.5 \mathrm{unit} / \mathrm{mL} \text { for ELBW infants when volume exceeds } 150 \mathrm{~mL} / \mathrm{kg} / \mathrm{d}\end{array}$ \\
\hline Potassium (K) as chloride or phosphat & $\begin{array}{l}2-4 \mathrm{mEq} / \mathrm{kg} / \mathrm{d} \\
\text { Consider omitting in ELBW infants } \\
\text { until renal sufficiency is well } \\
\text { established }\end{array}$ \\
\hline Chloride (Cl) & $\begin{array}{l}2-4 \mathrm{mEq} / \mathrm{kg} / \mathrm{d} \\
\text { Usual } \mathrm{Na}: \mathrm{Cl} \text { is } 1: 1\end{array}$ \\
\hline Excess anions & Excess anion equivalent $=\left(\mathrm{Na}^{+} \mathrm{K}\right)-\left(\mathrm{Cl}^{+} \mathrm{P}\right)$ \\
\hline Acetate & Usually provide electrolytes as acetate always use \\
\hline Chloride & acetate if adding cysteine hydrochloride for ELBW \\
\hline Calcium (Ca) as gluconate & $\begin{array}{l}1-3 \mathrm{mEq} / \mathrm{kg} / \mathrm{d} \text { for maintenance } \\
3-4.5 \mathrm{mEq} / \mathrm{kg} / \mathrm{d} \text { for growth (see text for solubility limits) } \\
\text { Should be administered through a central line rather than a peripheral line in premature infants }\end{array}$ \\
\hline $\begin{array}{l}\text { Phosphorus }(\mathrm{P}) \text { as sodium } \\
\text { or potassium phosphate } \\
\text { Magnesium }(\mathrm{Mg})\end{array}$ & $\begin{array}{l}1.3 \mathrm{mmol} / \mathrm{kg} / \mathrm{d} \text { for maintenance }[29] \\
1.5-2.0 \mathrm{mmol} / \mathrm{kg} / \mathrm{d} \text { for growth } \\
0.25-1.0 \mathrm{mEq} / \mathrm{kg} / \mathrm{d} \\
\text { Begin ELBW infants at low end } \\
\text { Increased needs for infants with } \\
\text { ostomy losses }\end{array}$ \\
\hline Vitamins as MVI-pediatric & $\begin{array}{l}\text { Premature: } 2 \mathrm{ml} / \mathrm{kg} / \text { day to a maximum of } 5 \mathrm{~mL} / \mathrm{d} \\
\text { Term: } 5 \mathrm{~mL} / \mathrm{d}\end{array}$ \\
\hline Zinc (Zn) as sulfate or in PTE solution & $\begin{array}{l}400 \mu \mathrm{g} / \mathrm{kg} / \mathrm{d}: \text { Preterm infants and all infants with gastrointestinal losses } \\
250 \mu \mathrm{g} / \mathrm{kg} / \mathrm{d}: \text { Term infants } 0-3 \text { months } \\
100 \mu \mathrm{g} / \mathrm{kg} / \mathrm{d}: \text { Term infants }>3 \text { months and all infants with long-term PN }\end{array}$ \\
\hline Copper (as sulfate or in PTE) & $\begin{array}{l}\text { Withhold during the first } 2 \text { weeks of PN, then initiate at } 20 \mu \mathrm{g} / \mathrm{kg} / \mathrm{day} \\
\text { Decrease amount or withhold with complication of obstructive jaundice }\end{array}$ \\
\hline Selenium in PTE & $\begin{array}{l}\text { Withhold during the first } 2 \text { weeks of PN } \\
\text { Decrease amount or withhold with complication of renal dysfunction }\end{array}$ \\
\hline Chromium in PTE & $\begin{array}{l}\text { Premature: Begin at } 1.3 \mu \mathrm{g} / \mathrm{kg} / \mathrm{d} \text { and advance to } 1.5-2.0 \mu \mathrm{g} / \mathrm{kg} / \mathrm{d} \\
\text { Term: } 2.0 \mu \mathrm{g} / \mathrm{kg} / \mathrm{d}\end{array}$ \\
\hline
\end{tabular}


Table 2: (Continued)

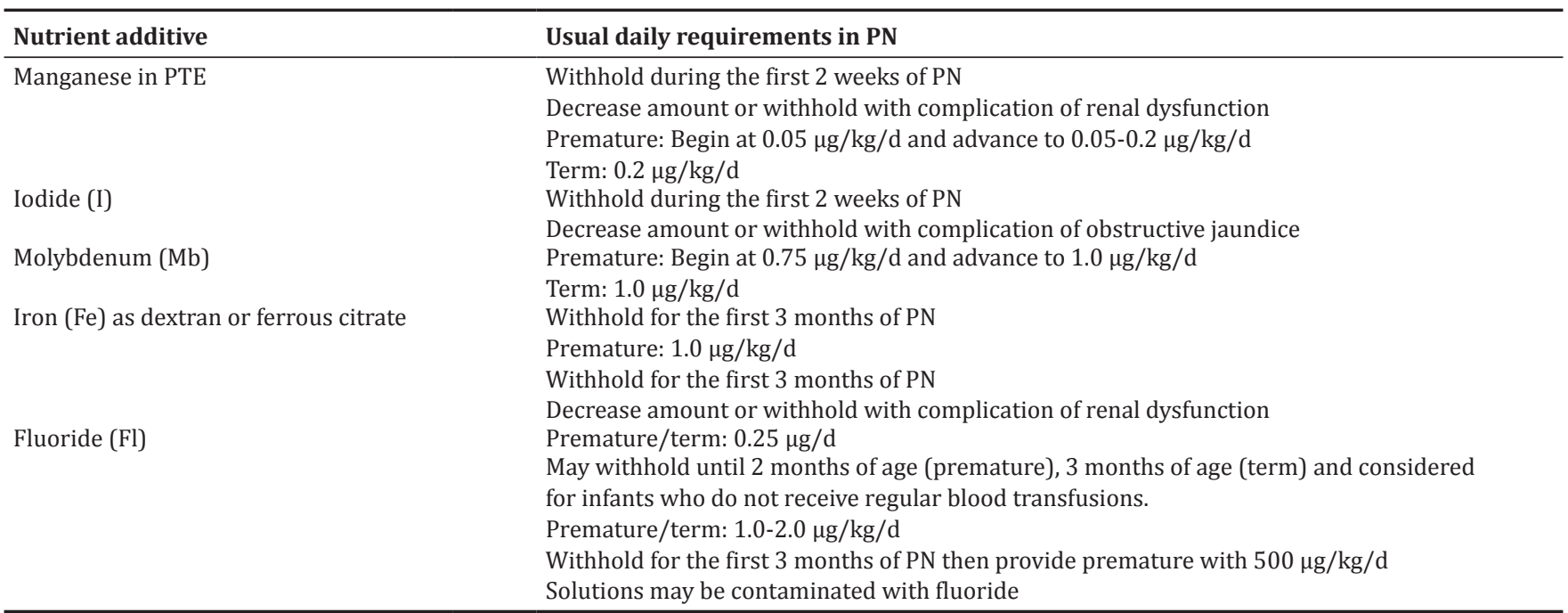

PN: Parenteral nutrition, PTE: Pediatric trace element, MVI: Multivitamin for infusion, ELBW: Extremely low in birth weight

is also considered as conditionally essential in premature infants due to a theoretical insufficiency of enzymatic activity for the conversion of methionine to cysteine. Cysteine is not contained in amino acid solutions because of problems with long-term stability and addition as aseparate solution as the solution is prepared is compatible and is needed to meet recommendations [50]. Cysteine hydrochloride supplements may cause metabolic acidosis, and therefore, PN solutions may need to be buffered with acetate [12].

Other special amino acid solutions designed specifically for patients with hepatic failure, renal disease, and higher protein needs have not been studied in infants and therefore are not recommended for infants. Amino acid profiles of these solutions are summarized elsewhere [51]. Amino acid solutions provide $4.0 \mathrm{kcal} / \mathrm{g}$ of protein. In neonates, protein accretion is thought to more adequately reflect nutritional status than weight gain [52]. Studies in preterm babies who receive PN suggest that protein accretion occurs by amino acid stimulation of protein synthesis rather than by suppression of protein break down $[17,53]$.

Protein requirements for the neonate tend to be inversely related to gestational age and size due to more rapid growth rates and greater protein losses in the smaller, more premature infants $[54,55]$. The early provision of protein is critical to attain positive nitrogen balance and accretion, as premature babies lose $\sim 1 \%$ of their protein stores daily [54,55]. The studies suggest the provision of at least $1 \mathrm{~g} / \mathrm{kg} / \mathrm{d}$ of amin acids can decrease catabolism [16,38,56]. ELBW infants can generally receive $2 \mathrm{~g} / \mathrm{kg} / \mathrm{d}$ of amino acids on the $1^{\text {st }}$ day of life $[16,57]$.

A classic study by Zlotkin et al. [36] suggests a protein goal of at least 2.7-3.5 g/ kg/d with the adequate energy of $>70$ nonprotein $\mathrm{kcal} / \mathrm{kg} / \mathrm{d}$ to approximate in utero nitrogen accretion. Studies show that early and aggressive provision of $3 \mathrm{~g}$ protein $/ \mathrm{kg} / \mathrm{d}$ and adequate nonprotein energy within the first few days of life is safe and effective at providing protein to meet accretion needs and facilitate intrauterine growth rates $[15,34]$. Protein requirements may be increased to counter catabolic or excretory losses in clinical conditions such as postoperative wound-healing, chronic lung disease treated with steroids, lymphatic injury with a sustained chyle leak, and/or during sustained periods when infants require limited or withheld enteral feeding or higher amounts of protein for catch-up growth [43,56-59].

To date, there is no evidence from randomized trials to support the routine use of parenteral or enteral glutamine supplementation in preterm infants $[59,60]$. Studies in critically ill adults suggest that glutamine supplemented amino acid solutions may reduce mortality, improve nitrogen balance, and reduce the incidence of clinical infection [47].
Fat

Fat is delivered as lipid emulsions of neutral triglycerides (TG), primarily polyunsaturated fatty acids (PUFAs) that are essential for normal growth and development, retinal development and function, brain development, and cell structure and function. Lipid emulsions provide a concentrated source of energy, $10 \mathrm{kcal} / \mathrm{g}$ of fat that enables the provision of nutrient intakes to premature infants within limited fluid volumes to achieve in utero rates of growth. Adequate administration of lipids prevents essential fatty acid deficiency, promotes positive nitrogen balance, and optimizes energy utilization. Solutions with $100 \%$ soy oil provide $54 \%$ of energy as linoleic acid and $8 \%$ as linolenic acid, whereas the $50 \%$ soy and $50 \%$ safflower mixture provides $66 \%$ of energy as linoleic acid and only $4.2 \%$ of energy as linolenic acid. Recommendations to prevent essential fatty acid deficiency in premature infants are to provide at least $80 \mathrm{kcal} / \mathrm{kg} / \mathrm{d}$, which will limit utilization of stored fat for energy and thus preserve docosahexaenoic acid and arachidonic acid stores [61,62]. An intake of linoleic acid is recommended at $4-5 \%$ of total calories and that of linolenic acid at $1 \%$ of total calories $[61,63]$.

Based on a minimal intake of $80 \mathrm{kcal} / \mathrm{kg}$, a fat intake of $0.6-0.8 \mathrm{~g}$ fat $/ \mathrm{kg}$ will meet linoleic acid recommendations and $1.0 \mathrm{~g}$ fat $/ \mathrm{kg}$ will meet linolenic acid recommendations from a solution that is $100 \%$ soy. Because the $50 \%$ soy and $50 \%$ safflower mixture provides less linolenic acid, the amount required to meet recommendations is $2.0 \mathrm{~g}$ fat $/ \mathrm{kg}$. Lipid emulsions are available as 10 and 20\% solutions; $20 \%$ solutions require less fluid volume and provide a lower phospholipid-to-TG ratio and therefore are recommended for premature infants. Lipid solutions also available with shorter chain and monounsaturated fats from olive oil and medium chain TG (MCT) oil. When compared with the longer chain TG solutions, those that contain MCT and olive oil provide a greater vitamin E to PUFA ratio, lower serum cholesterol, and are hydrolyzed more rapidly, but they may not be as effective in promoting protein accretion [64].

A $20 \%$ IV fat emulsion is typically started at $0.5-1 \mathrm{~g}$ fat $/ \mathrm{kg}$ on the first day of life generally at the same time amino acids are started to prevent the occurrence of essential fatty acid deficiency as well as to provide a more generous source of calories. The lipid emulsion is advanced as tolerated in incremental rates of $0.5-1 \mathrm{~g} / \mathrm{kg} / \mathrm{d}$ to a typical maximum of $3 \mathrm{~g} / \mathrm{kg} / \mathrm{d}$ [48].

In a balanced PN solution, this generally approximates about $30 \%$ of total calories from fat. Fluid-restricted, growth-compromised patients or those limited to peripheral line access may require as high as 3.5-4 $\mathrm{g} \mathrm{fat} / \mathrm{kg} / \mathrm{d}$ to achieve adequate energy for growth and protein 
sparing. This intake is appropriate as long as the fat intake remains $<60 \%$ of nonprotein calories. In neonates, the maximal removal capacity of plasma lipids was shown to be $0.3 \mathrm{~g} / \mathrm{kg} / \mathrm{hr}$. To minimize the occurrence of hyperlipemia, bilirubin displacement, and respiratory compromise, lipid infusion rates $\leq 0.15 \mathrm{~g} / \mathrm{kg} / \mathrm{hrs}$ are recommended to span over $24 \mathrm{hrs}$. The delivery of $3 \mathrm{~g} / \mathrm{kg} / \mathrm{d}$ of a $20 \%$ lipid emulsion equates to an infusion rate of $0.125 \mathrm{~g} / \mathrm{kg} / \mathrm{hr}[48,65]$.

Premature infants have limited fat stores and lipoprotein lipase concentrations that may hinder their ability to clear plasma lipids following infusions of IV fat [15]. The use of heparin dosing at 0.5-1 units/ $\mathrm{mL}$ of total parenteral nutrition solutions, with a maximum of 137 units/d, can facilitate lipoprotein lipase activity to help stabilize serum $\mathrm{TG}$ values $[43,64]$.

Lipids may be restricted in patients with hyperbilirubinemia in minimum amounts that will provide only the essential fatty acids. Some clinicians will reduce or withhold lipids if rising bilirubin trends approach levels requiring exchange transfusions. Because both lipids and bilirubin are transported in the blood by albumin, lipids competing for binding sites on albumin may result in insufficient binding of bilirubin to facilitate excretion [49]. Persistently, high bilirubin values may increase the risk of kernicterus from the deposition of bilirubin in brain cells. A free fatty acid to albumin ratio (FFA: Albumin) $>6: 1$ is thought to be clinically significant $[57,67]$.

\section{Micronutrients}

Electrolytes

Sodium, potassium, and chloride are essential to life and requirements are dependent on obligatory losses, abnormal losses, and amounts necessary for growth. Estimated and advisable intakes are based on accretion studies and urinary and fecal losses from balance studies completed in the late 1970s [26]. Sodium and potassium can be given as chloride, lactate, or phosphate salts. Infants who receive electrolytes solely as chloride salts may develop hyperchloremic metabolic acidosis. Sodium can also be given as acetate; a randomized trial in 1997 demonstrated the utility of acetate in PN solutions [27]. Potassium is added when the urinary flow is established and sodium is added postdiuresis. Chloride is generally given as sodium chloride. Thorough and up-to-date discussions of fluid and electrolyte management of premature infants are published elsewhere $[26,28]$.

\section{Major minerals}

Calcium, phosphorus, and magnesium are the most abundant minerals in the body. They are closely interrelated to each other in metabolism, the formation of tissue structure, and function. Amounts of calcium and phosphorus are initiated at maintenance levels and advanced when energy and protein intakes are adequate to support intrauterine accretion rates of lean tissue [29]. The adequacy of these nutrients from PN solutions has been studied extensively in the premature population and in-depth discussions appear elsewhere [30,31,68-72].

\section{Trace minerals}

Recommended amounts for trace minerals are listed in Table 3. The 1988 American Society of Clinical Nutrition (ASCN) guidelines [73] are given for term and preterm infants and compared with the 1993 consensus recommendations of an international panel of experts for preterm infants that are defined as transitional (within the first 2 weeks' of life) and stable (after 2 weeks' of age) [74]. Zincis universally recommended from day one of PN, whereas the other trace minerals are generally provided after 2, 4, or 12 weeks' of PN without any appreciable enteral feeding. Copper, selenium, molybdenum, and iron can be delivered separately also. Several trace element solutions are available with varying combinations of zinc, copper, chromium, manganese, and/or selenium [31]. Copper and manganese are discontinued from $\mathrm{PN}$ solutions with the complication of cholestasis, and amounts of chromium, selenium, and molybdenum are reduced or omitted when renal output is low [73]. Many of the component solutions to PN are found to be "contaminated" with trace elements, and therefore, administration before actual need may increase risk for toxicity [52,75-78]. Some have suggested copper requirements greater than the $20 \mu \mathrm{g} / \mathrm{kg} / \mathrm{d}$ recommendation $[30,73,74,79]$.

Because of the oxidant effect of copper as well as the risk of toxicity from limited excretion in patients with cholestasis, Greene et al. [73] advise the lower amount. Minimal enteral feedings are also a source of copper within the first 2 weeks. Although they may cause allergic reactions, iron dextran and ferrous citrate can be used to supplement PN solutions. Parenteral iron supplementation may be delayed until 2 months of age in premature infants and 3 months of age in term infants and considered for those infants who do not receive regular blood transfusions [31]. Concern for iron overload is related to increased risk for septicemia in malnourished infants with a low serum transferrin as well as an increased need for vitamin E $[31,73,80]$. Even though recommendations for premature infants exist within the first 2 weeks of life for copper, selenium, chromium, iron, iodide, and manganese, these trace minerals generally are not added to PN but are provided within minimal enteral feedings. Supplementation with iodide may not be necessary because needs for iodide may be met from the topical absorption of iodide-containing disinfectants, detergents, and other environmental sources [73].

Table 3: Amounts of trace minerals recommended for term and preterm infants in $\mathrm{PN}^{\mathrm{a}}$

\begin{tabular}{|c|c|c|c|c|}
\hline \multirow{3}{*}{$\begin{array}{l}\text { Trace } \\
\text { elements }\end{array}$} & \multirow{3}{*}{$\begin{array}{l}\text { Term }(\mu \mathrm{g} / \mathrm{kg} / \mathrm{d}) \\
\text { ASCN (1988) }\end{array}$} & \multicolumn{2}{|l|}{ Preterm $(\mu \mathrm{g} / \mathrm{kg} / \mathrm{d})$} & \multirow[t]{3}{*}{ ASCN (1998) } \\
\hline & & \multicolumn{2}{|l|}{ Consensus recommendations (1993) } & \\
\hline & & Transitional (first 2 weeks of life) & Stable ( $>2$ weeks old) & \\
\hline \multicolumn{5}{|l|}{ Chromium $^{\mathrm{b}}$} \\
\hline Copper ${ }^{c, d}$ & 0.20 & $0-0.05$ & $0.05-0.2$ & 0.2 \\
\hline Iron $^{\mathrm{e}}$ & 20 & $0-20$ & 20 & 20 \\
\hline Flouride $\mathrm{f}$ & - & $0-200$ & $100-200$ & - \\
\hline Iodide & - & & - & - \\
\hline Manganese $^{c}$ & 1.0 & 1.0 & 1.0 & 1.0 \\
\hline Molybdenum $^{\mathrm{b}}$ & 1.0 & $0-0.75$ & 1.0 & 1.0 \\
\hline Selenium $^{\mathrm{b}}$ & 0.25 & 0 & 0.25 & 0.25 \\
\hline \multirow[t]{2}{*}{ Zinc $^{\mathrm{g}}$} & 2.0 & $0-1.3$ & $1.5-2.0$ & 2.0 \\
\hline & 250 & 150 & 400 & 400 \\
\hline
\end{tabular}

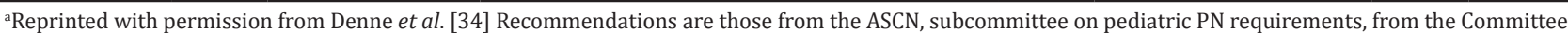
on Clinical Practice Issues, 1988, 25 and Greene et al. [74]. ${ }^{\text {b} R e n a l ~ d y s f u n c t i o n ~ c a n ~ c a u s e ~ t o x i c i t y . ~}{ }^{\mathrm{c} I m p a i r e d}$ biliary excretion can cause toxicity. ${ }^{\mathrm{d}} \mathrm{Greater}$

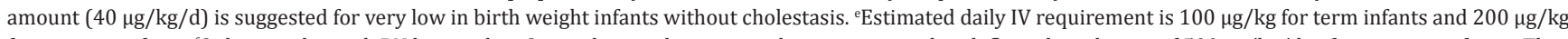

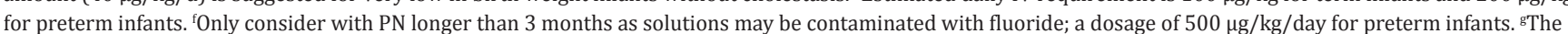
only trace element recommended on day 1 of TPN. When TPN is required_3 months, decrease dosage to 100 g/ $/ \mathrm{kg} / \mathrm{d}$. PN: Parenteral nutrition, ASCN: American Society of Clinical Nutrition 


\section{Vitamins}

The most recent guidelines for parenteral vitamin administration for infants remain those published as the consensus recommendations from an international panel of experts in 1993 [74]. These are compared in Table 4 to those recommended in 1988 by the ASCN [73]. For the most part, recommended intakes are based on serum vitamin concentrations measured in term and preterm infants who received various amounts of different vitamins [73]. These studies were primarily completed in infants $>1000 \mathrm{~g}$ at birth. Thus, specific needs of ELBW infants remain unclear [81]. There commended parenteral vitamin intakes can only be approximately delivered from multivitamin for infusion (MVI) pediatric. The standard dose of $2 \mathrm{~mL} / \mathrm{kg} / \mathrm{d}$ with a maximum intake of $5 \mathrm{~mL} / \mathrm{d}$ provides lower amounts of vitamin A and higher amounts of most of the $B$ vitamins (Table 4). Furthermore, IV vitamin delivery may be less due to photodegradation of vitamins A, D, E, K, B2, B6, B12, C, and folic acid and adsorption of vitamins $A, D$, and $E$ into the vinyl delivery bags and tubing [43]. Some clinicians have addressed these issues with the protection of delivery equipment from light and the administration of fat-soluble vitamins with lipid $[82,83]$. The need for a newly formulated pediatric MVI solution that better meets the premature infant's needs has been discussed and recommendations for its composition have been suggested $[30,73]$.

\section{COMPLICATIONS ASSOCIATED WITH PN}

Complications associated with PN therapy can be categorized into mechanical, metabolic, and infectious problems. The pharmacist must be aware of these complications and how they are likely to present, when they are likely to occur, and what can be done to prevent them.

\section{Mechanical}

Mechanical complications are catheter-related and may occur shortor long-term. Short-term complications are those related to catheter insertion and include pneumothorax, hemothorax, subclavian artery injury, air embolism, thoracic duct injury, catheter embolization, and catheter malposition [84]

Long-term mechanical complications include catheter occlusion, thrombosis, and catheter breakage. Catheter occlusion is the most frequent noninfectious mechanical complication seen with the use of long-term venous access devices. It may be due to a blood clot, fibrin sheath, drug or calcium precipitate, or catheter pinch-off syndrome. Occlusion can be prevented by correct catheter position, a routine flushing protocol with heparinized saline, monitoring of drug and nutrient incompatibilities, and use of in-line filters [85].

Thrombosis development can be promoted by catheter malposition or injury to the vein wall during or after catheter insertion, or it can be chemically induced. The catheter tip should be positioned at the junction of the superior vena cava and the right atrium. Venous thrombosis can be manifested by neck or arm swelling or pain. Treatment depends on the extent of the thrombus, the need to maintain current access, and the severity of symptoms. The conservative approach is to leave the catheter in place and to give anticoagulation therapy. Catheter removal may be warranted with extended thrombus $[86,94]$.

\section{Metabolic}

Metabolic complications are clearly the problem area, in which pharmacists can have the most input into prevention and treatment. These complications can be categorized as short- and long-term issues. In the hospitalized patient, PN is usually infused over $24 \mathrm{hrs}$, and as the patient is transitioning to home or long-term care, the PN solution is cycled (given over a shorter period of time such as 6-12 hrs). Usually, the infusion rate is increased over the first several hours and decreased (tapered) over the last hours of the infusion period. This will help temper some of the short-term metabolic complications that are described below. Short-term complications include refeeding syndrome, hyperglycemia and hypoglycemia, mineral and electrolyte imbalances, and hypertriglyceridemia. Most of these can be prevented with careful monitoring, proper nutrient dosing, and conformation to standard PN labeling guidelines [92].

Refeeding syndrome is one of the most critical complications that occur with the initiation of PN. It has been elegantly described by Solomon and Kirby [87] and is defined as the metabolic and physiologic consequences of the depletion, repletion, compartmental shifts, and interrelationships of phosphorus, potassium, magnesium, glucose metabolism, vitamin deficiency, and fluid resuscitation. More specifically, as an extremely malnourished individual is started on PN, cardiopulmonary and neurologic complications may occur as a result of hypokalemia, hypophosphatemia, and hypomagnesemia among

Table 4: Amounts of vitamins recommended for term and preterm infants in PN solutions compared to prescribed dosages of MVI-pediatric ${ }^{\mathrm{a}}$

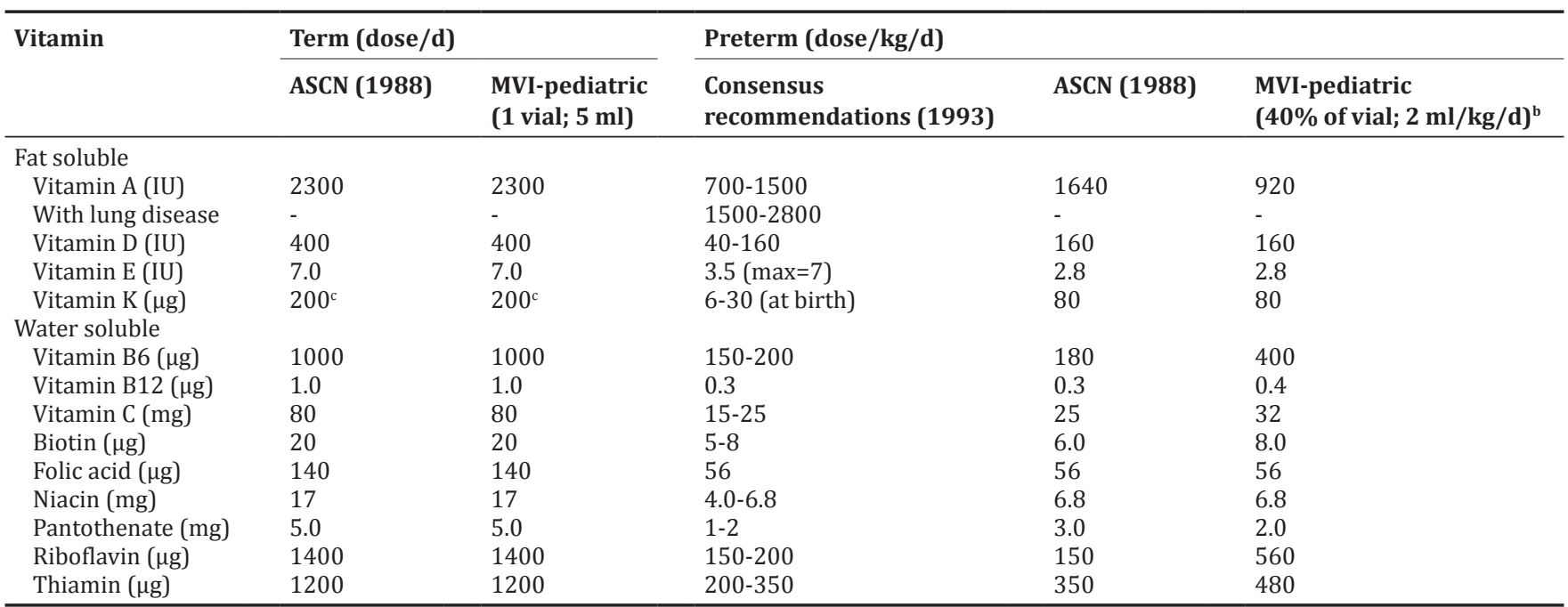

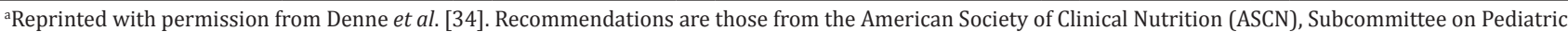
PN Requirements, from the Committee on Clinical Practice Issues, 1988, [73] and Greene et al. [74]. Needs of the Preterm Infant: Scientific Basis and Practical Guidelines. Baltimore, Williams These recommendations are currently not achievable because no ideal IV vitamin preparation is available for preterm infants; $40 \%$ of a vial $\left(2 \mathrm{ml} / \mathrm{kg} / \mathrm{d}\right.$ ) of MVI-pediatric (Armor, USA, Rover, Canada) is the closest intake that can be achieved at this time. ${ }^{\mathrm{b}}$ Maximum not to exceed a dosage of $5 \mathrm{ml} / \mathrm{d}$. ${ }^{\mathrm{T}} \mathrm{This}$ does not include the 0.5-1.0 mg of vitamin K given at birth, as recommended by the American Academy of Pediatrics [48]. PN: Parenteral nutrition, ASCN: American Society of Clinical Nutrition, MVI: Multivitamin for infusion 
other reasons. Risk factors for refeeding include alcoholism, anorexia nervosa, marasmus, rapid refeeding, and excessive dextrose infusion. The prevention of refeeding syndrome includes repletion of potassium, phosphorus, and magnesium; limiting dextrose dosing initially; limiting sodium in early PN solutions [95].

Hyperglycemia is the most common metabolic complication associated with PN. Risk factors include metabolic stress, concurrent glucocorticoid therapy, diabetes, obesity, sepsis, and excessive dosage of glucose. The prevention includes limiting glucose administration to $2-3 \mathrm{mg} / \mathrm{kg} / \mathrm{minutes}$ for at-risk patients, and $5 \mathrm{mg} / \mathrm{kg} /$ minutes in others, along with monitoring glucose every 6-8 hrs. The treatment includes decreasing the glucose dosage, administering regular insulin to keep glucose levels from 150 to $200 \mathrm{mg} / \mathrm{dl}$, or both $[89,96]$.

Hypoglycemia occurs most often when PN is suddenly discontinued. This can happen with occlusion of the central venous catheter, malfunction of the IV pump, or cycling off the PN. It can be prevented by slowly tapering the infusion rate and monitoring blood glucose concentration 1-2 hrs after the PN is discontinued [97].

Mineral and electrolyte imbalances include elevated or deficient levels of sodium, potassium, calcium, magnesium, phosphorus, or chloride. The most common imbalances that occur with PN are hyponatremia resulting an excess of hypotonic fluid, hypokalemia resulting from inadequate potassium intake, intracellular shifts or excessive GI losses, hypophosphatemia resulting from inadequate phosphorus intake or intracellular shifts, and hypomagnesemia resulting from alcoholism and refeeding syndrome. These imbalances can be prevented by providing an adequate dose of minerals and electrolytes as suggested in the ASPEN safe practices report and providing recommended volume requirements of $20-40 \mathrm{ml} / \mathrm{kg} /$ day to prevent fluid overload or dehydration [92]. The treatment for these imbalances includes assessing excess losses and repleting minerals and electrolytes in the PN solution when possible (calcium-phosphorus compatibility limitations may prevent full repletion via the PN solution) [5].

Hypertriglyceridemia may occur in patients who are unable to metabolize the IV lipids. Patients with baseline hypertriglyceridemia such as those with sepsis, AIDS, or lipid-induced acute pancreatitis may need to have lipid-free or low-dose-lipid PN. Monitoring of the TG level elevation over baseline after a low dose of lipids will help gauge whether patients must have lipid-free PN or whether a daily, continuous, lowdose infusion can be tolerated [90].

Long-term metabolic complications include hepatic dysfunction, metabolic bone disease, and trace element deficiencies. Hepatic dysfunction associated with PN is considered to be of a multifactorial nature. Causes include infusion of carbohydrates at an excess of $5 \mathrm{mg} / \mathrm{kg} / \mathrm{minutes}$ and sepsis. Steatosis occurs and can cause an elevation of transaminases and alkaline phosphatase days to weeks after initiation of PN. Elevated bilirubin concentration is seen less often, and enzymes lost often return to normal after the PN is discontinued. Treatment options include giving at least one-third of calories as lipids, cycling PN over 12 hrs to decrease continuously elevated insulin levels, and using the GI tract to stimulate bile flow [91,98].

Metabolic bone disease is a well-documented complication of long-term PN therapy. It may demonstrate itself as back pain, periarticular bone pain, or fracture. Adults may exhibit hypercalcuria due to excessive infusion of fluid, sodium, magnesium, phosphate, vitamin D, or amino acids [99].

Trace element deficiencies may occur in patients receiving long-term PN. Periodic zinc, chromium, iron, copper, and selenium levels should be measured, and these trace elements repleted as necessary [100].

\section{Infectious}

Infectious complications can occur anytime during the course of PN therapy. The two general sources of these complications are catheterrelated infection and solution-infusate contamination. The risk of catheter-related bloodstream infection remains one of the most serious complications associated with PN [101]. Temporary or short-term central venous catheters account for about $90 \%$ of nosocomial blood stream infections, and only $10 \%$ of infections are from long-term devices such as tunneled catheters or implanted reservoirs [102].

Risk factors for catheter-related infection include age $\geq 60$ years, increased severity of illness, distant site of infection, skill of inserter, use of catheter, and site of catheter placement [103]. The patients can also develop local site infections, port pocket infections, or catheter tunnel infections without developing a full blood stream infection. Signs and symptoms associated with catheter-related sepsis include fever, rigors, malaise, defervescence of fever after catheter removal, and positive blood cultures [102]. Treatment options include catheter removal, antibiotic lock, or delivery of systematic antibiotics via the catheter [93]. The prevention of a catheter-related infection can be aided by trained personnel with the use of aseptic technique in catheter placement and routine site care, flushing protocols, and tubing changes. Clinical monitoring for catheter-related infections includes assessing the patient's temperature, complete blood cell count with differential count, blood glucose level (sudden hyperglycemia may be an early warning sign), and the catheter insertion site [103].

\section{COMPATIBILITY OF PN}

The patients receiving PN therapy often required concomitant drug therapy. Most patients have adequate venous access or have multiple lumen central venous catheters so that mixing medications with the PN formulation is not that issue. However, for some patients with limited venous access, directly added medications or piggybacking medication via a secondary infusion must be considered. The compatibility of these medications and other IV solutions is an important concern in delivering safe and effective drug and nutritional therapy. IV medications are infused most often as separate admixture piggybacked in the PN line. However, some medications may be added directly to PN solution and administered at the same rate as the PN infusions. Because of the potential for ineffective drug therapy or other complication associated with physiochemical incompatibility and stability of the PN solution, specific criteria should be considered before one add a medication directly to PN solution [107].

Since PN is infused intravenously, it is often considered as a vehicle for medication administration. Medication may be added to PN formulations in an effort to decrease fluid requirements, reduce the need for Y-site injections, reduce the possibility of line contamination due to manipulation and decrease labor time required for drug administration. Although these reasons may seem compelling, the physicochemical complexity of PN formulations makes their interactions with parenteral medications a very challenging compatibility dilemma [6].

The stability and compatibility of total PN mixtures compounded for patients requiring nutritional support is paramount to their safety on IV infusion. The most significant pharmaceutical issues associated with mixing total PN formulations affecting their safety involve the stability of lipid-injectable emulsions and the compatibility of calcium and phosphate salts [99].

Drug-nutrient interactions result in derangements in fluid and electrolyte homeostasis, changes in vitamin status, and disturbances acid-base balance. Recognition of these drug-nutrient interactions may assist the clinician to prevent metabolic complications and to achieve desired therapeutics outcomes $[99,100]$. A major disadvantage to the use of PN solutions as drug delivery vehicles is the lack of compatibility and stability data in the PN solutions that are used commonly in clinical practice.

\section{PN and drug therapy}

Patients requiring PN suffer from severe functional or anatomical failure of the gastrointestinal tract. The decreased intestinal absorption affects the fate of xenobiotics like drugs leading to erratic or absent 
bioavailability. To overcome the lack of IV access and to reduce complicated drug treatments the use of a PN admixture as a vehicle for drug treatment is attractive. However, admixing of a solubilized drug to an All-in-one (AIO) PN must meet good manufacturing practice to avoid microbial contamination, to guarantee a defined formulation, and to prevent medication errors. It should be also kept in mind that the admixing of a drug to PN creates a new formulation with changed properties. This may eventually affect both the bioavailability of the PN and of the drug. The literature background is sparse. The variety of PN regimens and of drug dosages is huge. Therefore, pharmaceutical expertise is mandatory for safe and effective treatment $[88,101,102]$.

\section{Incompatibilities and interactions}

Incompatibilities include physicochemical reactions occurring in vitro. Pharmacological interactions take place in vivo and affect drug action (synergy or antagonism, adverse drug reactions). AIO mixtures constitute the standard for $\mathrm{PN}$; in the ready to use form they show restricted stability and shelf life. The high number of chemically reactive components and the oil/water $(\mathrm{o} / \mathrm{w})$ emulsion character of lipid-containing AIO admixtures represent a most complex vehicle for drug admixing [102]. Incompatibilities may result from direct reactions between soluble components but also from reactions with the container material or with the gas (oxygen) present in the container. These physicochemical reactions depend on concentration, temperature, and other co-factors such as light exposure and catalysts (trace elements) $[97,104,105]$. When drugs are added via a Y-site infusion or injection, or by a three-way-stopcock, except for the exposure time (time-dependent reactions), there is no general difference regarding incompatibility reactions in this situation (Table 5) [106].

The following aspects of drug admixing to feeds will be considered (Fig. 1) [106]:

- Changes of the emulsion character of the PN formulation

- $\quad$ Reaction of the drug formulation with the AIO bag material (ethyl vinyl acetate [EVA], polyvinyl chloride [PVC], polyolefin, etc.)

- Reactions with specific nutrients leading to inactivation (oxidation, etc.)

- Reactions with components leading to toxicity (e.g., precipitation, radical formation).

\section{Emulsion changes}

The $\mathrm{o} / \mathrm{w}$ emulsion of an AIO admixture is stabilized by amphiphilic phospholipid emulsifier (lecithin). Stability is also dependent on the source of the TGs, the amino acid pattern, the glucose content (viscosity), the electrolyte and trace element concentration, and the $\mathrm{pH}$. In a $\mathrm{pH}$ range of $5-8$, the negatively charged phosphate moiety of the emulsifier prevents coalescence of the small oil droplets $(250-500 \mathrm{~nm}$ diameter) by electric repulsion [101].

However, this zeta potential is decreased by (polyvalent) cationic agents including positively charged drugs (aminoglycosides) or divalent cationic drug salts (Ca- or Mg heparin). Reduced repulsion forces between the oil droplets eventually lead to irreversible creaming and oiling out $[1,102,104]$.

Therefore, drug formulations with a low pH (e.g., midazolam and vancomycin) or a very high $\mathrm{pH}$ (aciclovir, furosemide, metoclopramide, phenytoin, barbiturates, etc.) should not be admixed to lipid-containing AIO admixtures without emulsion dispersal testing, e.g., by light microscopy. Highly lipophilic drugs (log Poctanol _3) dissolved as micelles by amphiphilic solvents like cremophors or tweens may also interact with the lipid emulsion. The resulting formulation, even when showing increased o/w emulsion stability, may change the biodisposition of the drug and of the TGs (FFA release). Similar reactions may occur with other lipophilic drugs like paclitaxel or amphotericin B showing small therapeutic indices too. The same has to be considered for liposomal formulations. Such drug admixing should be omitted in the absence of documented effectiveness and safety of the treatment $[103,106]$.
Table 5: Incompatibility reactions

\begin{tabular}{ll}
\hline Chemical reactions & Physical reactions \\
\hline $\begin{array}{l}\text { Oxidation/Reduction } \\
\text { (catecholamines) }\end{array}$ & $\begin{array}{l}\text { Precipitation (solubility) } \\
\text { (midazolam } \mathrm{pH}>5 \text { ) } \\
\text { (beta-lactam antibiotics) } \\
\text { Polymerization, }\end{array}$ \\
$\begin{array}{l}\text { Sorption (diazepam and PVC) } \\
\text { (Maillard products) }\end{array}$ & Permeation (iodine) \\
$\begin{array}{l}\text { Permeation (iodine) } \\
\text { Cleaving reactions } \\
\text { (prostaglandins) } \\
\text { Racemate formation } \\
\text { (L-n-epinephrine) }\end{array}$ & \\
Epimerization (tetracyclines) & \\
Complex formation & Destabilization of disperse systems \\
(Ca p quinolones) & Thermal reactions \\
\hline
\end{tabular}

PVC: Polyvinyl chloride

\section{Container Material}<smiles>C1CCCCC1</smiles>

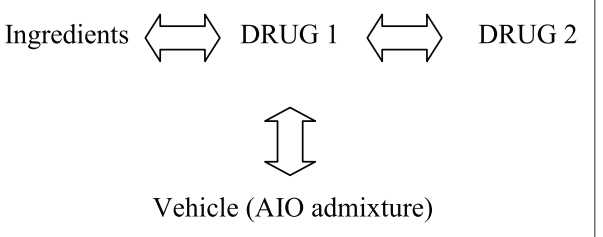

Fig. 1: Incompatibility reactions in parenteral nutrition

\section{Incompatibilities with the bag material}

For lipid containing AIO admixtures plastic bag material without softeners is mandatory because of their potential extraction by lipids, e.g., phthalates from PVC. EVA and polyolefins (multi-layered foils) are common container materials without softeners. Significant amounts of lipophilic drugs - such as diazepam, nitroglycerine, and dihydropyridines - may be absorbed into (PVC) plastic material. Protein drugs - such as albumin, insulin, and growth factors - may also be adsorbed on the container surface. Therefore, such drugs should not be added to large volume parenteral feeds to avoid loss of active drug [104,106].

\section{Inactivation of drugs or PN components}

$\mathrm{PN}$ is not an inert vehicle but contains essential nutrients intended to be administered unchanged. The organic nutrients contain aldehyde-, $\mathrm{OH}$ - or amino-groups (glucose, amino acids) or conjugated double bonds (PUFA) prone to chemical reaction with corresponding compounds. Such drugs are characterized by reduced stability and a high incompatibility profile (e.g., catecholamines). Most short acting medications, used especially in Intensive Care Unit, show high chemical reactivity. They should not be added to AIO admixtures due to potential rapid inactivation [102].

The presence of trace elements such as iron, copper, and selenium may even catalyze oxidative or reductive degradation of drugs (epinephrine) or nutrients (ascorbic acid). Such reactions are only partly accompanied by color changes of the solution (Maillard reaction) and are not always detectable by visual inspection. In contrast, ultraviolet spectrophotometry may be able to assess such drug inactivation because of the specific absorption analysis of the respective compound. Chelators included in drug dosage forms for stability reasons may interfere with trace element or electrolyte availability (e.g., EDTA in propofol formulations) [102,107] 


\section{Degradation reactions leading to potential activity}

The solubility of drugs very much depends on the $\mathrm{pH}$ of the solution because of the acid/base character of most drugs (pKa). Variation in $\mathrm{pH}$ among different producers of the same drug may also be relevant and make extrapolation difficult. Weak acids or weak bases need high or low $\mathrm{pH}$ to form water-soluble salts. When added to a buffered AIO admixture, precipitates are formed reducing the drug and/or nutrient concentration according the solubility product. Local $\mathrm{pH}$ differences may even be more pronounced with Y-site or three-way-stopcock administration. Precipitates may be harmful or even fatal. An inline filter is not always a guarantee of preventing precipitates being infused. As an example, Ca phosphate precipitate is formed when the solubility product is exceeded. The salt is more soluble in the cold and may therefore only precipitate if the PN admixture is warmed up. In contrast to binary PN admixtures, lipid-containing AIO admixtures cannot be assessed visually and filters of $1.2 \mathrm{~mm}$ pore size used for lipid emulsion do not eliminate small particles. Therefore, drugs dissolved at $\mathrm{pH}<5$ or $>7$ (alkaloids, virostatic drugs, vancomycin, etc.) are a problem in PN admixtures. Lipid peroxidation of PUFA results in radical formation, which can be harmful to the patient. Drugs sensitive to oxidation/reduction processes may react with PUFA or radicals and modulate peroxidation chain reactions. Molecules like tricyclic phenothiazenes (chlorpromazine) easily interact with such electron transfer processes and are therefore unsuitable for AIO admixing [103,107].

\section{Practical guidelines for drug therapy [103,104,106,107]}

- Patients with PN should have a multi-lumen catheter for medication therapy

- AIO admixtures represent a most complex and reactive vehicle for drug admixing not suitable for most drugs (incompatibilities)

- Intermittent IV administration with sufficient rinsing fluid has to be preferred to admixing whenever possible

- Pharmaceutical advice from the nutrition team has to be respected in every situation where therapeutic drug admixing is necessary

- Physicochemical characterization of the drug formulation is a prerequisite to estimate possible compatibility $(\mathrm{pH}, \mathrm{pKa}$, physicochemical stability of the active ingredient, formulation additives, etc.)

- Molar concentration ratios between reaction partners have to be considered

- Admixing is possible only immediately before administration at maximal dilution

- Check the therapeutic effect of the admixed drug as an indirect bioavailability test

- The use of standard PN formulations and standard drug protocols will allow the establishment of a data base for reference.

No admixing when:

- Presence of solubilizers to dissolve lipophilic drugs (ethanol, cremophor, etc.)

- Drugs with chemical instabilities (lyophilisates)

- Small therapeutic indices of the drug (cytotoxics, etc.)

- Short elimination half-lives of the drug (limited variation in administration speed).

Admixing possible when:

- Sufficient stability reported (literature, experimental analysis)

- Drug formulation compatible with pH of AIO admixture

- No ingredients with incompatibilities with AIO admixtures (divalent cations)

- Large therapeutic index of the drugs involved (analgesics, sedatives, H2-antagonists)

- Aseptic admixing and documented protocol given (pharmacy with controlled areas)

- Simple stability testing possible (pH, lipid droplet size analysis, inspection for coloration and precipitation)

- In-line filter.

\section{REFERENCES}

1. NICE. Guideline, Nutrition Support in Adults. Excellence, UK: National Institute for Health and Clinical; 2006.

2. Wilmore DW, Dudrick SJ. Growth and development of an infant receiving all nutrients exclusively by vein. JAMA 1968;203:860-4 .

3. American Society of Consultant Pharmacists. Consultant Pharmacists. Vol. 14. Arlington, VA: American Society of Consultant Pharmacists; 1999. p. 371-6.

4. Koletzko B, Goulet O, Hunt J, Krohn K, Shamir R; Parenteral Nutrition Guidelines Working Group, et al. Guidelines on paediatric parenteral nutrition of the European Society of Paediatric Gastroenterology, Hepatology and Nutrition (ESPGHAN) and the European Society for Clinical Nutrition and Metabolism (ESPEN), Supported by the European Society of Paediatric Research (ESPR). J Pediatr Gastroenterol Nutr 2005;41 Suppl 2:S1-87.

5. Mirtallo J, Canada T, Johnson D, Kumpf V, Petersen C, Sacks G, et al. Safe practices for parenteral nutrition. JPEN J Parenter Enteral Nutr 2004;28(6):S39-70.

6. Mirtallo J. Assessment Tools and Guidelines: Parenteral Nutrition Therapy. Cleveland, OH: McMahon Publishing; 2008.

7. Dudrick SJ, Wilmore DW, Vars HM, Rhoads JE. Long-term total parenteral nutrition with growth, development, and positive nitrogen balance. Surgery 1968;64(1):134-42.

8. Heird WC, Driscoll JM Jr, Schullinger JN, Grebin B, Winters RW. Intravenous alimentation in pediatric patients. J Pediatr 1972;80:351-72.

9. Koletzko B. Early nutrition and its later consequences: New opportunities. Adv Exp Med Biol 2005;569:1-12.

10. Tsang R, Koletzko B, Uauy R, Zlotkin S. Nutrition of the Preterm Infant. Scientific Basis and Practical Application. Cincinnati: Digital Educational Publishing; 2005.

11. Royal College of Paediatrics and Child Health. Withholding or Withdrawing Life Saving Treatment in Children. A Framework Forpractice. London: RCPCH; 1997.

12. Brine $\mathrm{E}$, Judith AE. Total parenteral nutrition for premature infants. Newborn Infant Nurs Rev 2004;4(3):133-55.

13. Lemons J, Bauer C, Oh W, Korones S, Papile L, Stoll B, et al. Very low birth weight outcomesof the National Institute of Child Health and Human Development Neonatal Research Network, January 1995 through December 1996. Pediatrics 2001;107:el. Available from: http://www.pediatrics.org/cgi/content/full/107/1/el.

14. Hack M, Fanaroff AA. Outcomes of children of extremely low birthweight and gestational age in the 1990's. Early Hum Dev 1999;53:193-218.

15. Thureen P. Early aggressive nutrition in the neonate. NeoReviews 1999;20(9): $45-55$

16. Thureen PJ, Hay WW Jr. Intravenous nutrition and postnatal growth of the micropremie. Clin Perinatol 2000;27:197-219.

17. Thureen PJ, Melara D, Fennessey PV, Hay WW Jr. Effect of low versus high intravenous amino acid intake on very low birth weight infants in the early neonatal period. Pediatr Res 2003;53:24-32.

18. Heird W. The importance of early nutritional management oflowbirthweight infants. NeoReviews 1999;20:e43-4.

19. Poindexter B, Denne S. Protein needs of the preterm infant. NeoReviews 2003;4:E52-8.

20. Wilson D, Cairns P, Halliday H, Reid M, McClure G, Dodge. Randomized controlled trialof an aggressive nutritional regimen in sick very low birthweight infants. Arch Dis Child Fetal Neonatal Ed 1997;77:4F-11.

21. Hay W, Lucas A, Heird W. Workshop summary: Nutrition of theextremely low birth weight infant. Pediatrics 1999;104:1360-8.

22. Dusick A, Vohr B, Steichen J, Wright L, Mele L. Factors affecting growthoutcome at 18 months in extremely low birthweight (ELBW) infants. Pediatr Res 1998;43:213A.

23. Vohr BR, Wright LL, Dusick AM, Mele L, Verter J, Steichen JJ, et al. Neurodevelopmental and functional outcomes of extremely low birth weight infants in the National Institute of Child Health and Human Development Neonatal Research Network, 1993-1994. Pediatrics 2000;105(6): 1216-26.

24. Price P. Parenteral nutrition: Administration and monitoring. In: GrohWargo S, Thompson M, Cox J, Hartline JV, editors. Nutritional Care for High-Risk Newborns. $3^{\text {rd }}$ ed. Chicago, IL: Precept Press; 2000. p. 91-118.

25. Anderson D. Parenteral nutrition: Fluid and electrolytes. In: GrohWargo S, Thompson M, Cox J, Hartline J, editors. Nutritional Care for High-Risk Newborns. $3^{\text {rd }}$ ed. Chicago, IL: Precept Press; 2000. p. $109-18$ 
26. Ziegler EE, O’Donnell AM, Nelson SE, Fomon SJ. Body composition of the reference fetus. Growth 1976;40(4):329-41.

27. Peters O, Ryan S, Matthew L, Cheng K, Lunn J. Randomised controlled trial of acetate in preterm neonates receiving parenteral nutrition. Arch Dis Child Fetal Neonatal Ed 1997;77(1):F12-5.

28. Yardley R. Sodium, potassium and chloride. In: Yu V, MacMahon R, editors. Intravenous Feeding of the Neonate. London: EdwardArnold; 1992. p. 64-7.

29. Vileisis RA. Effect of phosphorus intake in total parenteral nutrition infusates in premature neonates. J Pediatr 1987;110:586-90.

30. Schanler RJ. The low birth weight infant. In: Walker WA, Watkins JB, Duggan C, editors. Nutrition in Pediatrics: Basic Science and Clinical Application. $3^{\text {rd }}$ ed. London: BC Decker; 2003. p. 491-514.

31. Krug S. Parenteral nutrition: Vitamins, minerals and trace elements. In: Groh-Wargo S, Thompson M, Cox J, Hartline JV, editors. Nutritional Care for High-Risk Newborns. $3^{\text {rd }}$ ed. Chicago, IL: Precept Press; 2000. p. 151-76.

32. Hertz DE, Karn CA, Liu YM, Liechty EA, Denne SC. Intravenous glucose suppresses glucose production but not proteolysis in extremely premature newborns. J Clin Invest 1993;92:1752-8.

33. Sulkers EJ, Lafeber HN, Degenhart HJ, Przyrembel H, Schlotzer E, Sauer PJ. Effects of high carnitine supplementation on substrate utilization in low-birth-weight infants receiving total parenteral nutrition. Am J Clin Nutr 1990;52:889-94.

34. Denne S, Poindexter B, Leitch C. Nutrition and metabolism in the highrisk neonate, Part 2: Parenteral nutrition. In: Fanaroff A, Martin R, editors. Neonatal-Perinatal Medicine. $7^{\text {th }}$ ed. St. Louis, MO: Mosby; 2002. p. 598-617.

35. Leitch C, Denne S. Energy expenditure in the extremely low birth weight infant. In: Cowett R, editor. Nutrition and Metabolism of the Micropremie. $1^{\text {st }}$ ed., Vol. 27. Philadelphia, PA: Saunders; 2000. p. 181-95

36. Zlotkin SH, Bryan MH, Anderson GH. Intravenous nitrogen and energy intakes required to duplicate in utero nitrogen accretion in prematurely born human infants. J Pediatr 1981;99(1):115-20.

37. Bell E. Nutritional support. In: Goldsmith J, Karotkin E, editors. Assisted Ventilation of the Neonate. Philadelphia, PA: Saunders; 1996. p. 381-95

38. Ziegler EE. Protein in premature feeding. Nutrition 1994;10(1):69-71

39. Thureen PJ, Anderson AH, Baron KA, Melara DL, Hay WW Jr, Fennessey PV. Protein balance in the first week of life in ventilated neonates receiving parenteral nutrition. Am J Clin Nutr 1998;68:1128-35

40. Premer DM, Georgieff MK. Nutrition for ill neonates. Pediatr Rev 1999;20:e56-62.

41. Denne SC, Kalhan SC. Glucose carbon recycling and oxidation in human newborns. Am J Physiol 1986;251:E71-7.

42. Lifshitz C. Carbohydrate Needs in Preterm and Term Infants. Vol. 122. Philadelphia, PA: Hanley and Belus; 1988

43. Reiter P, Thureen P. Nutrition support in neonatology. In: Gottschlich M, editor. The Science and Practice of Nutrition Support: A Case-Based Core Curriculum. Dubuque, IA: Kendall/Hunt; 2001. p. 323-46.

44. Baker S, Davis A. Pediatric Parenteral Nutrition. New York: International Thomson Publishing; 1997.

45. Kanarek K, Santeiro M, Malone J. Continuous infusion of insulin in hyperglycemic low-birth weight infants receiving parenteral nutrition with and without lipid emulsion. J Parenter Enteral Nutr $1991 ; 15: 417-20$

46. Henry B. Pediatric parenteral nutrition support. In: Nevin-Folino N, editor. Pediatric Manual of Clinical Dietetics. $2^{\text {nd }}$ ed. Chicago: Faulhabes; 2003, p. 495-514.

47. Shulman RJ. New developments in total parenteral nutrition for children. Curr Gastroenterol Rep 2000;2:253-8

48. American Academy of Pediatrics. Pediatric Nutrition Handbook. $5^{\text {th }}$ ed. Elk Grove Village, IL: American Academy of Pediatrics; 2004.

49. Aba-Sinden A, Bollinger R. Challenges and controversies in the nutrition support of the preterm infant. Support Line 2002;2:2-15

50. Heird WC, Gomez MR. Parenteral nutrition in low-birth-weight infants. Annu Rev Nutr 1996;16:471-99.

51. Ernst J, Gross S. Types and methods of feedings for infants. In: Polin R, Fox W, editors. Fetal and Neonatal Physiology. $2^{\text {nd }}$ ed. Philadelphia, PA: Saunders; 1998. p. 363-82.

52. Hak EB, Storm MC, Helms RA. Chromium and zinc contamination of parenteral nutrient solution components commonly used in infants and children. Am J Health Syst Pharm 1998;55:150-4.

53. Denne SC, Karn CA, Ahlrichs JA, Dorotheo AR, Wang J, Liechty EA. Proteolysis and phenylalanine hydroxylation in response to parenteral nutrition in extremely premature and normal newborns. J Clin Invest 1996; $97: 746-54$

54. Heird WC. Amino acid and energy needs of pediatric patients receiving parenteral nutrition. Pediatr Clin North Am 1995;42(4):765-89.

55. Heird W, Discoll J. Total parenteral nutrition. NeoReviews 2003;4:e137-9.

56. Van Goudoever JB, Colen T, Wattimena JL, Huijmans JG, Carnielli VP, Sauer PJ. Immediate commencement of amino acid supplementation in preterm infants: Effect on serum amino acid concentrations and protein kinetics on the first day of life. J Pediatr 1995;127:458-65.

57. Mayhew SL, Gonzalez ER. Neonatal nutrition: A focus on parenteral nutrition and early enteral nutrition. Nutr Clin Pract 2003;18(5):406-13.

58. Embleton N, Pang N, Cooke R. Postnatal malnutrition and growth retardation: An inevitable consequence of current recommendations in preterm infants? Pediatrics 2001;107(2):270-3

59. Tubman TR, Thompson SW. Glutamine supplementation for prevention of morbidity in preterm infants. Cochrane Database Syst Rev 2001;CD001457.

60. Poindexter BB, Ehrenkranz RA, Stoll BJ, Koch MA, Wright LL, Oh W, et al. Effect of parenteral glutamine supplementation on plasma amino acid concentrations in extremely low-birth-weight infants. Am J Clin Nutr 2003;77:737-43

61. Innis S. Fat. In: Tsang R, Lucas A, Uauy R, Zlotkin S, editors. Nutritional Needs of the Preterm Infant Scientific Basis and Practical Guidelines. Baltimore, MD: Williams and Wilkins; 1993. p. 65-86.

62. Tsang R, Uauy R, Koletzko B, Zlotkin S, editors. Nutrition of the Preterm Infant: Scientific Basis and Practical Application. $2^{\text {nd }}$ ed. Cincinnati: Digital Educ Publ; 2005. p. 97-139.

63. Innis S. Lipids in parenteral nutrition. NeoReviews 2002;3(3):c48-55.

64. Uauy R, Treen M, Hoffman DR. Essential fatty acid metabolism and requirements during development. Semin Perinatol 1989;13:118-30.

65. Gustafson A, Kjellmer I, Olegard R. Nutrition in low-birthweight infants. I. Intravenous injection of fat emulsion. Acta Paediatr Scand 1972;61:149-58.

66. Putet G. Lipid metabolism of the micropremie. Clin Perinatol 2000;27:57-69, v-vi.

67. ASPEN Board of Directors and the Clinical Guidelines Task Force. Guidelines for the use of parenteral and enteral nutrition in adult and pediatric patients. JPEN J Parenter Enteral Nutr 2002;26 1 Suppl:1SA-138.

68. Andrew G, Chan G, Schiff D. Lipid metabolism in the neonate. I. The effects of Intralipid infusion on plasma triglyceride and free fatty acid concentrations in the neonate. J Pediatr 1976;88(2):273-8.

69. Krug S. Osteopenia of prematurity. In: Groh-Wargo S, Thompson J, Cox T, editors. Nutritional Care for High Risk Newborns. $3^{\text {rd }}$ ed. Chicago, IL: Precept Press; 2000. p. 489-505.

70. Koo W, Tsang R. Mineral requirements of low-birth-weight infants. J Am Coll Nutr 1991;10:474-84.

71. Koo W, Steichen J. Osteopenia and rickets of prematurity. In: Polin R, Fox W, editors. Fetal and Neonatal Physiology. $2^{\text {nd }}$ ed. Philadelphia, PA: Saunders; 1998. p. 2335-49.

72. Prestridge LL, Schanler RJ, Shulman RJ, Burns PA, Laine LL. Effect of parenteral calcium and phosphorus therapy on mineral retention and bone mineral content in very low birth weight infants. J Pediatr $1993 ; 122: 761-8$

73. Koo W, Tsang R. Calcium, phosphorus, magnesium and vitamin D requirements of infants receiving parenteral nutrition. In: Yu V, MacMahon R, editors. Intravenous Feeding of the Neonate. London: Edward Arnold; 1992. p. 68-75.

74. Greene HL, Hambidge KM, Schanler R, Tsang RC. Guidelines for the use of vitamins, trace elements, calcium, magnesium, and phosphorus in infants and children receiving total parenteral nutrition: Report of the Subcommittee on Pediatric Parenteral Nutrient Requirements from the Committee on Clinical Practice Issues of the American Society for Clinical Nutrition. Am J Clin Nutr 1988;48:1324-42.

75. Tsang R, Lucas A, Uauy R, Zlotkin S. Nutritional Needs of the Preterm Infant: Scientific Basis and Practical Guidelines. Baltimore, MD: Williams and Wilkins; 1993

76. Hardy G, Reilly C. Technical aspects of trace element supplementation. Curr Opin Clin Nutr Metab Care 1999;2:277-85.

77. Van Gossum A, Neve J. Trace element deficiency and toxicity. Curr Opin Clin Nutr Metab Care 1998;1(6):499-507.

78. Dickerson RN. Manganese intoxication and parenteral nutrition. Nutrition 2001;17(7-8):689-93.

79. Pluhator-Murton M, Fedorak R, Audette R, Marriage BJ, Yatscoff RW, Gramlich LM. Trace element contamination of total parenteral nutrition. 1. Contribution of component solutions. JPEN J Parenter 
Enteral Nutr 1999;23(4):222-7.

80. Tyrala E. Trace elements. In: Yu V, MacMahon R, editors. Intravenous Feeding of the Neonate. London: Edward Arnold; 1992. p. 76-97.

81. Greer FR. Vitamin metabolism and requirements in the micropremie. Clin Perinatol 2000;27(1):95-118, vi.

82. Werkman SH, Peeples JM, Cooke RJ, Tolley EA, Carlson SE. Effect of vitamin A supplementation of intravenous lipids on early vitamin A intake and status of premature infants. Am J Clin Nutr 1994;59(3):586-92.

83. Laborie S, Lavoie JC, Pineault M, Chessex P. Protecting solutions of parenteral nutrition from peroxidation. JPEN J Parenter Enteral Nutr 1999;23(2):104-8

84. Sax HC. Complications of total parenteral nutrition and their prevention. In: Rombeau JL, Caldwell MD, editors. Clinical Nutrition: Parenteral Nutrition. $2^{\text {nd }}$ ed. Philadelphia, PA: WB Saunders; 1993.

85. Safe practices for parenteral nutrition formulations. National Advisory Group on Standards and Practice Guidelines for Parenteral Nutrition. JPEN J Parenter Enteral Nutr 1998;22(2):49-66.

86. Andris DA, Krzywda EA. Central venous access. Clinical practice issues. Nurs Clin North Am 1997;32:719-40.

87. Solomon SM, Kirby DF. The refeeding syndrome: A review. JPEN J Parenter Enteral Nutr 1990;14(1):90-7.

88. Skipper AL, Millikan KW. Parenteral nutrition implementation and management. In: The ASPEN Nutrition Support Practice Manual. Silver Spring, MD: American Society for Parenteral and Enteral Nutrition; 1998.

89. McMahon M, Manji N, Driscoll DF, Bistrian BR. Parenteral nutrition in patients with diabetes mellitus: Theoretical and practical considerations. JPEN J Parenter Enteral Nutr 1989;13(5):545-53.

90. Goff K. Metabolic monitoring in nutrition support. Nurs Clin North Am 1997:32:741-53.

91. Fleming CR. Hepatobiliary complications in adults receiving nutrition support. Dig Dis 1994;12(4):191-8.

92. Koo WW. Parenteral nutrition-related bone disease. JPEN J Parenter Enteral Nutr 1992;16:386-94.

93. Baumgartner TG. Trace elements in clinical nutrition. Nutr Clin Pract 1993;8:251-63.

94. Murphy LM, Lipman TO. Central venous catheter care in parenteral nutrition: A review. JPEN J Parenter Enteral Nutr 1987;11:190-201.

95. Pearson ML. Guideline for prevention of intravascular device-related infections. Hospital Infection Control Practices Advisory Committee. Infect Control Hosp Epidemiol 1996;17:438-73.

96. Pearson ML. Centers for Disease Control and Prevention: Guidelines for prevention of intravascular device-related infection. Part I. Intravascular device-related infections: An overview. The Hospital Infection Control Practices Advisory. Am J Infect Control 1996;24(4):262-77.

97. Kimble K, Lloyd YY, Wayne AK, Joseph G. Applied Therapeutics. $7^{\text {th }}$ ed. Philadelphia, PA: Lippincott William; 2002.

98. Di Piro JT, Barbara GW, Terry LS, Cindy WH. Pharmacotherapy. $6^{\text {th }}$ ed. New York: McGraw Hill; 2006.

99. David F. Driscoll. Stability and compatibility assessment techniques for total parenteral nutrition admixtures: Setting the bar according to pharmacopeial standards. Curr Opin Clin Nutr Metab Care 2005;8(3):297-303

100. Trissel LA, Gilbert DL, Martinez JF. Compatibility of parenteral nutrient solutions with selected drugs during simulated Y-site administration. Am J Health-Syst Pharm 1997;54:1295-1300.

101. Driscoll DF, Baptista RJ, Mitrano FP, Mascioli EA, Blackburn GL, Bistrian BR. Parenteral nutrient admixtures as drug vehicles: Theory and practice in the critical care setting. DICP 1991;25:276-83.

102. Hardy G, Ball P, McElroy B. Basic principles for compounding all-inone parenteral nutrition admixtures. Curr Opin Clin Nutr Metab Care 1998; $1: 291-6$

103. Trissel LA, Gilbert DL, Martinez JF, Baker MB, Walter WV, Mirtallo JM. Compatibility of medications with 3-in-1 parenteral nutrition admixtures. JPEN J Parenter Enteral Nutr 1999;23(2):67-74.

104. King JC, Catania PN. Guide to Parenteral Admixtures. St. Louis, MO, USA: Pacemarq Inc.; 1991.

105. Mu"hlebach S. Basics in clinical nutrition: Drugs and nutritional admixtures. eSPEN Eur eJ Clin Nutr Metab 2009;4:e134-6.

106. ASPEN Board of Directors and Clinical Guidelines Task Force. Guidelines for the use of parenteral and enteral nutrition in adult and pediatric patients. Drug Nutr Interact JPEN 2002;26 1 Suppl:42SA

107. Trissel LA. Handbook of Injectable Drugs. $14^{\text {th }}$ ed. Bethesda, MD, USA: American Society of Hospital Pharmacists; 2007. 